\author{
RESEARCHPAPER
}

\title{
Studies on major stem pests and incremental cost benefit ration for different integrated pest management modules on soybean
}

\author{
A.A. MOTAPHALE, B.B. BHOSALE AND F.S. KHAN \\ Department of Entomology, Vasantrao Naik Marathwada Krishi Vidyapeeth, PARBHANI (M.S.) INDIA
}

Article Info : Received : 12.07.2016; Revised : 18.08.2016; Accepted : 05.09.2016

The stemfly (Melanagromyza sojae, Zehntner) and girdle beetle (Obereopsis brevis Swedenbord) are two major pests of soybean in this region during Kharif crop. It was felt imperative to develop IPM for these pests hence, this experimentation was carried out. Data revealed that MAU IPM module was effective in reducing the infestation of girdle beetle (6.30\%) and stem fly (7.95\%), whereas in chemical control infestation was (7.35\%) and (8.02\%) per cent in girdle beetle and stem fly, respectively. Considering the stem tunneled length it was found that girdle beetle and stem fly was (12.14\%) and (15.54\%) in MAU IPM module whereas in chemical control, it was (14.56\%) and (15.17\%) by girdle beetle and stem fly, respectively. Cost benefit ratio of these methods were compared, it was found that CBR was highest (1:7.65) in MAU IPM module followed by chemical control (1:5.82). MAU IPM module included the eco-friendly and sustainable methods to manage these major regular pests of soybean and which was found effective and economical methods.

Key words : IPM, Integrated pest management, Stem pest, Girdle beetle, Stem fly, Stem tunneling, Cost benefit ratio

How to cite this paper : Motaphale, A.A., Bhosale, B.B. and Khan, F.S. (2016). Studies on major stem pests and incremental cost benefit ration for different integrated pest management modules on soybean . Asian J. Bio. Sci., 11 (2) : 263-268.DOI : 10.15740/HAS/AJBS/11.2/263-268. 